\title{
Implementasi Sistem Informasi Administrasi Dalam Peningkatan Pelayanan Kesehatan Pada Puskesmas Bayan \\ ${ }^{1}$ M. Taufik Rachman, ${ }^{2}$ Nidya Putri Syahida ${ }^{3}$ Yana Isnaini \\ ${ }^{1}$ Administrasi Publik, Universitas Muhammadiyah Mataram, Indonesia \\ ${ }^{2}$ Administrasi Publik, Universitas Muhammadiyah Mataram, Indonesia
}

\section{INFO ARTIKEL}

Riwayat Artikel:

Diterima: 18-3-2018

Disetujui: 20-3-2018

Kata Kunci:

1. Sistem Informasi

2. Administrasi

3. Pelayanan Publik

\section{ABSTRAK}

Abstrak: Puskesmas Bayan adalah salah satu pusat pelayanan kesehatan yang berada di kabupaten Lombok Utara. Adapun kinerja sistem dalam pelayanan pasien yang berjalan di Puskesmas Bayan tersebut masih belum optimal karena pada pengolahan data masih dilakukan menggunakan media pembukuan. Banyak kendala yang dialami oleh pihak Puskesmas, diantaranya adanya kesalahan dalam melakukan input, penyimpanan data, serta dapat terjadi kerangkapan arsip pasien. Sehingga pengolahan data menjadi tidak efektif dan efisien. Ada beberapa persepsi masyarakat dan pegawai terhadap sistem informasi administrasi pelayanan kesehatan pada Puskesmas Bayan. Hal inilah yang menjadi ketertarikan penyusun dalam melakukan penelitian tentang persepsi pegawai terhadap penerapan sistem informasi administrasi dalam peningkatan pelayanan kesehatan pada puskesmas bayan dan dalam hal ini penulis menggunakan metode penelitian kualitatif dimana penelitian kualitatif yaitu mengkaji perspektif partisipan dengan strategi-strategi yang bersifat interaktif dan fleksibel.

Penelitian kualitatif ditujukan untuk memahami fenomena-fenomena sosial dari sudut pandang partisipan. Hasil yang diperoleh dari penelitian ini adalah sistem informasi administrasi yang diterapkan pada Puskesmas Bayan masih menggunakan sistem manual, yang artinya tetap menggunakan perangkat komputer tetapi tidak terhubung dengan jaringan data local area network (LAN) dan tidak menggunakan server sebagai database. Dari penelitian ini dapat disimpulkan bahwa sistem informasi pelayanan kesehatan pada Puskesmas Bayan sudah berjalan dengan baik meskipun terdapat beberapa kekurangan pada sarana prasaran dan sumber daya manusia.

\section{Abstract}

Health center of Bayan is one of the main health center is location in the north of Lombok district. As the performance of systems running in patient care in the health center of Bayan is still not optimal for the data processing is still done use media bookkeeping. Many of the constraints experienced by the health center, including an error in the input, data storage, and can occur double patient files. So that data processing becomes ineffective and inefficient. There are several public and employee perception of the administration of health care information system in health center Bayan. This is the author's interest in conducting research on employee perceptions of the application of information systems administration in the improvement of health services in health center Bayan and in this case the author uses qualitative research methods in which a qualitative study that examines the participants with strategies that are interactive and flexible. 
Keywods

1. Information System

2. Administration

3. Public Service
The qualitative research aimed at understanding social phenomena from the perspective of the participants. The results obtained from this study is an information system that is applied to the health center administration Bayan still using a manual system, which means keep using the computer but not connected to a data network local area network ( LAN) and does not use as a database server. From this study it can be concluded that the health care information system in health center Bayan already well underway although there are some deficiencies in the means of infrastructures and human resources.

\section{Latar Belakang}

Pemerintah dalam rangka mewujudkan tata pemerintahan yang baik, bersih dan berwibawa, dihadapkan pada pelaksanaan tugas yang sangat luas dan kompleks. Aparatur pemerintah dituntut untuk dapat menjalankan pelayanan-pelayanan kepada masyarakat secara efektif dan efisien serta mempunyai inisiatif dan empati di dalam menjalankan tugas-tugas dan fungsinya. Pada dasarnya penyelenggaraan pemerintah mengemban tiga fungsi hakiki yaitu pelayanan (service), pemberdayaan (empowerment), dan pembangunan (development) yang semua itu dilakukan oleh para aparatur pemerintah. Jadi selain melaksanakan pembangunan dan pemberdayaan aparatur pemerintah juga diharapkan dapat memberikan pelayanan yang maksimal terhadap masyarakat dalam segala pelayanan yang menyangkut kepentingan publik terutama pelayanan kesehatan masyarakat.

Dalam perkembangan ilmu pengetahuan dan teknologi di era globalisasi, kebutuhan akan sistem informasi yang cepat, akurat dan tepat waktu merupakan suatu hal yang mutlak dan sangat berpengaruh dalam berbagai bidang. Dengan adanya sistem informasi dapat mempermudah kita dalam melakukan pengolahan data sehingga dapat menghemat waktu, ruang, dan biaya. Untuk meningkatkan pelayanan kesehatan yang baik bagi masyarakat, perlu adanya perubahan dalam hal sistem yang digunakan agar lebih efektif dan efisien.

Pengolahan data untuk pelayanan kesehatan didalam masyarakat sangat penting. Dengan adanya pengolahan data dapat disusun suatu informasi untuk membantu proses pelayanan kesehatan yang dapat menyajikan segala kebutuhan informasi layanan kesehatan masyarakat. Puskesmas Bayan adalah salah satu pusat pelayanan kesehatan yang berada di kabupaten Lombok Utara. Adapun kinerja sistem dalam pelayanan pasien yang berjalan di Puskesmas Bayan tersebut masih belum optimal karena pada pengolahan data masih dilakukan menggunakan media pembukuan. Banyak kendala yang dialami oleh pihak Puskesmas, diantaranya adanya kesalahan dalam melakukan input, penyimpanan data, serta dapat terjadi kerangkapan arsip pasien. Sehingga pengolahan data menjadi tidak efektif dan efisien. Hal tersebut dapat menghambat jalannya laporan dan kelancaran dalam hal pelayanan kepada pasien.

\section{Tinjauan Pustaka}

\section{a. Pengertian Implementasi}

Pengertian implementasi dalam kamus Webster dalam Wahab dirumuskan secara pendek bahwa "to implement" (mengimplementasikan) berarti "to provide means for carriying out, to give pratical effect to" (menyajikan sarana untuk melaksanakan sesuatu, menimbulkan dampak/berakibat sesuatu.

Tiga kegiatan yang paling utama dalam implementasi adalah :

1. Penafsiran, yaitu merupakan kegiatan yang menerjemahkan makna program dalam pengaturan yang tepat diterima dan dapat dijalankan.

2. Organisasi, yaitu merupakan unit atau wadah untuk menempatkan program ke dalam tujuan kebijakan.

3. Penerapan yang berhubungan dengan perlengkapan rutin bagi pelayanan, upah dan lain-lainnya.

Menurut Wayne Persons (2006) bahwa implementasi adalah sebuah proses interaksi antara penentuan tujuan dan tindakan untuk 
mencapai tujuan. Sejalan dengan yang dikemukakan oleh Anderson dalam buku buku Wayne Persons, bahwa implementasi adalah pelaksanaan pembuatan kebijakan dengan cara-cara lain. Akan tetapi biasanya kita cenderung menganggap sistem publik sebagai suatu yang menambah problem, dengan menarik garis pemisah antara kebijakan dan administrasi.

\section{b. Kinerja Implementasi}

Menurut Van Meter dan Van Horn dalam Subarsono menyatakan bahwa ada enam variabel yang mempengaruhi kinerja implementasi yaitu :

1. Standar dan Sasaran Kebijakan

Standar dan sasaran kegiatan harus jelas dan terukur sehingga dapat direalisasikan. Apabila standar dan sasaran kebijakan kabur, maka akan terjadi multi interprestasi dan mudah menimbulkan komplik diantara para agen implementasi.

2. Sumber Daya

Implementasi perlu dukungan daya, baik sumber daya manusia maupun sumber daya non manusia.

3. Komunikasi dan Penguatan Aktivitas

Dalam implementasi program perlu dukungan dan koordinasi dengan instansi lain.

Untuk itu diperlukan koordinasi dan kerja sama antar instansi bagi keberhasilan suatu program.

4. Karakteristik Agen Pelaksana

Agar pelaksana mencakup struktur birokrasi, norma-norma, dan pola-pola hubungan yang terjadi dalam birokrasi, yang semuanya akan mempengaruhi implementasi suatu program.

5. Kondisi Sosial, Ekonomi dan Politik

Variabel ini mencakup sumber daya ekonomi, lingkungan yang dapat mendukung keberhasilan implementasi kebijakan, sejauh mana kelompokkelompok kepentingan dapat memberikan dukungan bagi implementasi kebijakan, karakteristik para partisipan yakni mendukung atau menolak, bagaimana sifat opini publik yang ada di lingkungan dan apakah elit politik mendukung implementasi kebijakan.

6. Disposisi Implementor

Disposisi implementor ini mencakup tiga hal, yaitu: respon implementor terhadap kebijakan, yang akan dipengaruhi kemauannya untuk melaksanakan kebijakan, kognisi yakni pemahamannya terhadap kebijakan, dan intensitas disposisi implementor, yakni preferensi nilai yang dimiliki oleh implementor.

\section{c. Konsep Dasar Sistem Informasi}

Sistem informasi dapat diidentifikasi sebagai suatu sistem di dalam suatu organisasi yang merupakan kombinasi dari orang-orang, fasilitas, teknologi, media prosedur-prosedur dan pengendalian yang ditujukan untuk mendapatkan jalur informasi penting, memproses tipe transaksi rutin tertentu, memberi sinyal kepada manajemen dan yang lainnya terhadap kejadian-kejadian internal dan eksternal yang penting dan menyediakan suatu dasar informasi untuk pengambilan keputusan.

Pengertian sistem informasi menurut Wilkinson (2000:4) merupakansuatu kerangka kerja dengan mana sumber daya (manusia, komputer) dikoordinasikan untuk mengubah masukan (data) menjadi keluaran (informasi), guna mencapai sasaran-sasaran perusahaan/instansi pemerintah". Sistem Informasi biasanya terdiri dari :

1. Hardware, terdiri dari komputer, printer dan jaringan.

2. Software, merupakan kumpulan dari perintah/fungsi yang ditulis dengan aturan tertentu untuk memerintahkan komputer melaksanakan tugas tertentu

3. Data, merupakan komponen dasar dari informasi yang akan di proses lebih lanjut untuk mendapatkan informasi.

4. Prosedur, dokumentasi prosedur/proses sistem, buku penuntun operasional (aplikasi0 dan teknis.

5. Manusia, yang terlibat dalam komponen manusia seperti operator, pemimpin sistem informasi dan lain-lain.

Kegiatan Sistem Informasi:

1. Input, menggambarkan suatu kegiatan untuk menyediakan data di proses.

2. Proses, menggambarkan bagaimana suatu data di proses untuk menghasilkan suatu informasi yang mempunyai nilai tambah.

3. Output, suatu kegiatan untuk menghasilkan laporan dari proses diatas tersebut.

4. Penyimpanan, suatu kegiata untuk memelihara dan menyimpan data.

5. Kontrol, suatu aktivitas untuk menjamin bahwa sistem informasi tersebut berjalan sesuai dengan yang diharapkan. 


\section{d. Pengertian Administrasi}

Pengertian administrasi itu dapat dikategorikan menjadi tiga maca, yaitu:

1. Istilah administrasi yang dipergunakan dalam pengertian proses atau kegiatan.

2. Istilah administrasi yang dipergunakan dalam pengertian tata usaha.

3. Istilah administrasi yang dipergunakan dalam pengertian pemerintah atau administrasi negara.

Beberapa pendapat yang mempersepsi istilah administrasi sebagai proses atau kegiatan, di antaranya:

1. Soetarto dan R.P Soewarno menyatakan bahwa administrasi adalah suatu proses penyelenggaraan dan pengurusan segenap tindakan kegiatan dalam setiap usaha kerjasama sekelompok manusia untuk mencapai tujuan.

2. LAN RI merumuskan administrasi sebagai kegiatan kerjasama dan upaya (organisasi dan manajemen) yang bersifat sistematis, rasional dan manusiawi yang dilakukan sekelompok orang untuk mencapai tujuan bersama.

Beberapa pendapat yang mempersepsi istilah administrasi sebagai tata usaha, di antaranya :

1. Munawardi Reksohasiprawiro mengatakan bahwa administrasi berarti tata usaha yang mencakup setiap pengaturan yang rapi dan sistematis serta penentuan fakta-fakta secara tertulis, dengan tujuan memperoleh pandangan yang menyeluruh serta hubungan timbal balik antara satu fakta dengan fakta yang lainnya.

2. Harris Muda mengatakan bahwa administrasi adalah suatu pekerjaan yang sifatnya mengatur segala pekerjaan yang berhubungan dengan tulis menulis, surat menyurat dan mencatat (membukukan) setiap perubahan/kejadian yang terjadi dalam organisasi itu.

Beberapa pendapat yang mempersepsi istilah administrasi pemerintah atau administrasi negara, di antaranya :

1. Wijana mengatakan administrasi adalah rangkaian dari semua organ-organ negara rendah dan tinggi, yang bertugas menjalankan pemerintah, pelaksanaan dan kepolisian.

2. Utrecht mengatakan bahwa administrasi adalah gabungan jabatan yang dibawah pimpinan pemerintah melakukan sebagian dari pekerjaan pemerintah (tugas pemerintah) yang tidak ditugaskan kepada badan-badan pengadilan, badan legislatif dan badan-badan pemerintah dari persekutuan-persekutuan hukum yang lebih rendah daripada negara.

\section{e. Tujuan Administrasi}

Adapun secara garis besar tujuan administrasi adalah sebagai berikut:

1. Memberikan ikhtisar-ikhtisar informasi yang dianalisa mengenai aktivitas-aktivitas operasional yang terdapat dalam kantor atau perusahaan.

2. Mengendalikan volume dan arus dana yang beredar.

3. Membantu sistem pengendalian untuk manajemen perusahaan/kantor dan memberikan atau menyediakan informasi keuangan.

4. Memenuhi kewajiban - kewajiban berdasarkan anggaran dasar perusahaan, undang-undang, peraturan pemerintah dan perjanjian-perjanjian dengan pihak ketiga untuk mengumpulkan data-data tertentu.

\section{d. Fungsi Administrasi}

Adapun secara garis besar fungsi administrasi adalah sebagai berikut:

1. Sebagai alat bukti.

2. Sebagai alat perhitungan dan pertanggung jawaban.

3. Sebagai alat untuk mengambil keputusan.

4. Sebagai alat untuk menetapkan hasil-hasil operasional.

5. Sebagai alat untuk memenuhi ketentuanketentuan yang terdapat dalam peraturan Undang-Undang dan Peraturan Pemerintah dan perjanjian-perjanjian dengan pihak ketiga.

\section{f. Pelayanan}

Pelayanan adalah suatu tindakan yang dilakukan untuk memenuhi kebutuhan orang lain (konsumen, pelanggan, tamu, pasien, penumpang dan lain-lain) pada tingkat pemuasannya hanya dapat dirasakan oleh orang yang melayani dan yang dilayani. Menurut Ndraha (2003) "Pelayanan dalam administrasi adalah pelayanan dalam arti kegiatan. Oleh karena itu administrasi terdapat dalam bentuk atau corak Negara apa saja, baik totaliter, otoriter, maupun demokratik". Juga menyatakan bahwa "konsep pelayanan meliputi proses, output (produk) dan outcome (manfaat)". 


\section{g. Pelayanan Publik}

Ratminto dan Winarsih (2006:5) mengemukakan bahwa pelayanan publik dapat didefinisikan sebagai segala bentuk jasa pelayanan baik dalam bentuk barang maupun jasa yang pada prinsipnya menjadi tanggung jawab dan dilaksanakan oleh instansi pemerintah di pusat, daerah dan lingkungan Badan Usaha Milik Negara/Daerah, dalam rangka upaya pemenuhan kebutuhan masyarakat maupun dalam rangka pelaksanaan ketentuan perundang-undangan. Selanjutnya menurut Johns (2003:450) mengatakan bahwa kunci untuk menciptakan rasa senang pelanggan masyarakat pelayanan yang diberikan berada satu langkah dari yang diharafkan pelanggan, yaitu dengan cara :

1. Meningkatkan standar lebih dari apa yang saat ini diharafkan oleh para pelanggan anda, sehingga mereka sungguh-sungguh menjadi puas daripada sekedar puas.

2. Memperkenalkan bentuk-bentuk baru costomer service sebelum adanya harapan pelanggan, melalui suatu proses yang dikenal secara luas sebagai pemasaran jasa.

\section{Metode Penelitian}

\section{a. Jenis Dan Metode Penelitian}

Jenis penelitian yang digunakan oleh penulis adalah jenis deskriptif. Suharsimin (1998:24) mengemukakan bahwa jenis penelitian deskriftif yaitu merupakan kajian non hipotesis sehingga dalam langkah penelitiannya tidak perlu merumuskan hipotesis.

Dalam penelitian skripsi ini Penulis menggunakan pendekatan yaitu metode penelitian kualitatif. Penelitian kualitatif menurut Sugyono (2009) yaitu mengkaji perspektif partisipan dengan strategi-strategi yang bersifat interaktif dan fleksibel. Penelitian kualitatif ditujukan untuk memahami fenomena-fenomena sosial dari sudut pandang partisipan.

Dengan demikian penelitian kualitatif adalah penelitian yang digunakan untuk meneliti pada kondisi objek alamiah dimana peneliti merupakan instrumen kunci.

\section{b. Sumber Data}

Sumber data primer adalah data yang didapat dari sumber pertama baik dari individu atau perorangan seperti hasil wawancara atau hasil pengisian kuesioner yang biasa dilakukan oleh peneliti.
Menurut Umar (2001:69) bahwa sumber data sekunder adalah data skunder yang telah diolah lebih lanjut dan disajikan baik oleh pihak pengumpul data primer atau oleh pihak lain misalnya dalam bentuk tabel-tabel atau diagram-diagram.

\section{c. Teknik Pengumpulan Data}

Sedangkan untuk memperoleh data yang diperlukan tersebut, penulis mempergunakan cara sebagai berikut:

\section{Observasi}

Obeservasi adalah pengamatan langsung kepada suatu objek yang akan diteliti. Metode observasi ini juga dapat dikatakan sebagai metode penelitian untuk mendapatkan data primer dengan mengadakan peninjauan langsung pada instansi yang dipilih menjadi objek penelitian dengan maksud untuk mendapatkan data yang berhubungan dengan hal yang akan ditelitiagar lebih meyakinkan dan akurat. (Keraf, 2001:162)

\section{Wawancara}

Wawancara yaitu suatu teknik pengumpulan data dengan mengadakan tanya jawab secara langsung kepada pihakpihak yang terkait mengenai data dan fakta yang diperlukan dalam penulisan penelitian ini. Hal tersebut sejalan dengan rumusan berikut : salah satu cara untuk memperoleh pengamatan langsung adalah wawancara kepada orang-orang yang kita maksud. Wawancara berbentuk pertanyaanpertanyaan yang berkenaan dengan tema yang diinginkan, dikerjakan langsung berhadapan dengan mereka yang diwawancarai. (Komaruddin, 1987:113)

\section{Dokumentasi}

Dokumentasi adalah metode pengumpulan data yang bersember pada benda-benda yang tertulis. (Suharsimi, 1998:149). Metode ini digunakan untuk memperoleh data mmengenai dokumen yang digunakan oleh instansi dalam mengelola sistem informasi administrasi di Puskesmas Bayan.

\section{Penelitian Kepustakaan (Librari Research)}

Secara umun teknik penelitian kepustakaan (library research) adalah teknik penelitian sebagai usaha untuk memperoleh keterangan an data dengan membaca dan mempelajari bahan-bahan teoritis dari buku-buku literatur, catatan- 
catatan kuliah, diktat, peraturan perundangundangan, majalah, artikel di internet dan sumber-sumber lainnya yang berhubungan dengan masalah yang diteliti agar diperoleh suatu pemahaman yang mendalam serta menunjang proses pembahasan mengenai masalah-masalah yang diidentifikasi.

\section{d. Teknik Analisa Data}

Seperti telah diuraikan pada sub bab yang terdahulu, bahwa jenis dari penelitian yang penulis laksanakan saat ini adalah deskriptif yaitu menggambarkan apa adanya dari sifat sampel yang diteliti. Maka untuk metode analisis data kualitatif dilakukan secara interaktif. Selanjutnya langkah-langkah yang digunakan dalam menganalisis data yang menggunakan metode interaktif sebagaimana dijelaskan Miles dan Huberman (Sugiyono, 2011:246) maka langkah-langkah analisis data yang digunakan yaitu reduksi data, penyajian data dan verifikasi data.

\section{Hasil dan Pembahasan}

\section{a. Tata Laksana Sistem Yang Berjalan}

Sistem yang berjalan pada administrasi pengobatan di Puskesmas Bayan berbeda antara pasien umum dan pasien yang menjadi tanggungan badan penyelenggara jaminan sosial (BPJS). Hal ini tercermin dalam wawancara dengan Kasubbag Tata Usaha Puskesmas Bayan, Wiwik Mulyati sebagai berikut :

"Syarat bagi pasien ketika mendaftar untuk pertama kalinya itu tergantung pasien dalam pembayaran, jika pasien bayar sendiri hanya memakai kartu tanda penduduk (KTP) saja. Sedangkan pasien yang memakai Askes atau BPJS maka memakai aturan pembayaran yang sudah ditentukan oleh Puskesmas Bayan dan pihak terkait". Ditambahkan pula : "Data yang dibutuhkan dan dituliskan dalam formulir pendaftaran mengenai data pasien antara lain mengenai nama, tanggal lahir, jenis kelamin dan status perkawinan."

Dalam pendaftaran atau registrasi pasien baik pasien lama maupun pasien baru, diharuskan datang secara langsung ke unit pendaftaran Puskesmas Bayan, hal ini dikarenakan unit pendaftaran Puskesmas Bayan belum melayani pendaftaran secara tidak langsung atau melalui telepon. Hal ini tercermin dalam wawancara langsung kepada
Kasubbag Tata Usaha Puskesmas Bayan, Wiwik Mulyati sebagai berikut :

"Kita belum bisa menerima pendaftaran melalui telepon, karena kami belum merancang program tersebut. Pasien diwajibkan datang langsung untuk mendaftar dan berobat".

Hal ini direspon oleh Kepala Puskesmas Bayan H. Husnul Ahadi, dalam hasil wawancara sebagai berikut :

"Hambatan dari penerapan sistem jaringan dalam komunikasi data terutama dari segi sumber daya manusia (SDM), harga dan sistem. Dari segi SDM hanya masalah keterampilan pegawai, adaptasi dari proses manual ke sistem komputer sedangkan untuk masalah harga dan sistem harus ada support atau dukungan dari instansi terkait".

\section{b. Proses Pengolahan Data Pada Puskesmas Bayan}

Didalam rangkaian sistem informasi pelayanan kesehatan yang dijalankan oleh Puskesmas Bayan, sub sistem input merupakan proses awal dari sebuah perjalanan proses informasi. Sub sistem input atau data masukan yaitu aktivitas pemasukan data seperti registrasi pasien, yang antara lain pencatatan dan pemeriksaan data pasien masuk atau berobat dengan tujuan untuk memperoleh keterangan atau informasi yang didalamnya terdapat kegiatan menghimpun data-data dan fakta-fakta yang relevan dengan permasalahan yang ada.

Dalam menghimpun data-data dan fakta maka tidak terlepas dari adanya sumber data, untuk itu maka yang menjadi sumber data disini adalah pasien Puskesmas Bayan baik pasien baru maupun lama. Data calon pasien dalam formulir pendaftaran mempunyai peranan dan fungsi yang penting dalam sub sistem input. Data tersebut meliputi nama, tempat tanggal lahir, jenis kelamin, pekerjaan, status perkawinan, kartu tanda penduduk (KTP), nomor telepon dan tanggal atau waktu kunjungan terakhir pasien.

Selanjutnya adalah sub - sistem proses, sub sistem proses merupakan suatu tahap berikutnya didalam perjalanan arus sistem informasi, dimana di dalam sistem informasi pelayanan kesehatan ini mekanisme pengolahan data untuk kemudian di simpan di dalam bank data. Bank data sendiri merupakan kumpulan-kumpulan data strategis dari unit kerja terkait. Dalam sub sistem 
proses ini meliputi kegiatan mengumpulkan data-data transaksi yang terjadi kemudian diolah menjadi laporan yang akan diberikan kepada pihak-pihak yang memerlukan, yaitu antara lain Departemen Kesehatan, Dinas Kesehatan Propinsi, Dinas Kesehatan kabupaten/Kota, Badan Penyelenggara Jaminan Sosial dan Puskesmas sebagai arsip.

Dalam proses pengolahan data disini, proses pemasukan data dilakukan oleh pihak yang berwenang, setelah data selesai maka akan disimpan untuk dibuat laporan sebagai bentuk output. Proses pengolahan data ini meliputi pengumpulan atau perekapan yang terjadi setiap hari untuk selanjutnya disimpan dan akan dibuat laporan baik untuk bulanan, tiga bulanan, tiap enam bulan dan laporan tahunan.

Hal ini tercermin dalam wawancara dengan Kepala Puskesmas Bayan, sebagai berikut ; "Dalam proses pengolahan data ini, data akan dicatat dan diproses yaitu melalui proses assembling yang dikerjakan menggunakan program excel oleh petugas unit rekam medis, setelah di export ke excel dan diolah, data yang sudah jadi tersebut di print untuk dijadikan laporan ke instansi yang telah ditentukan".

Hasil keluaran data merupakan hasil atau keluaran dari proses dalam sistem informasi. Didalamnya terdapat kegiatan untuk menyajikan dan mendistribusikan informasi yang ada kepada pihak yang memerlukan. Wujud dari informasi yang dihasilkan dalam output data sistem informasi pelayanan kesehatan ini adalah data laporan rutin bulanan, tribulanan, enam bulanan dan tahunan, yang bertujuan untuk mengukur mutu penyelenggara pelayanan kesehatan sesuai standar yang berlaku, sehingga pada gilirannya dapat diupayakan aplikasi yang relevan sesuai dengan hasil penyajian dan keluaran dari sistem informasi Puskesmas. Hal ini tercermin dalam wawancara dengan Kasubbag Tata Usaha Puskesmas Bayan, Wiwik Mulyati sebagai berikut :

"Sistem informasi pelayanan kesehatan di Puskesmas Bayan mempunyai peranan sangat penting, yaitu sebagai sumber data yang nantinya menghasilkan output data berupa informasi. Wujud dari informasi itu antara lain data laporan rutin bulanan, tribulanan, semester dan tahunan." c. Hambatan Dalam Implementasi Sistem Informasi Administrasi Di Puskesmas Bayan Dalam sistem informasi administrasi yang berjalan di Puskesmas Bayan menemukan beberapa hambatan yang mempengaruhi peningkatan pelayanan kesehatan antara lain :

1. Sistem informasi administrasi yang tidak terkoneksi jaringan data membuat pelayanan kurang efisien.

2. Dalam proses penyimpanan data hanya dapat disimpan di masing-masing komputer karena tidak ada server sebagai pusat data.

Untuk pasien umum masih menggunakan sistem manual yang membuat pelayanan kurang cepat dan akurat, sedangkan peserta jaminan sosial sudah bisa di akses secara online.

\section{Simpulan}

Dari hasil penelitian dan analisis peneliti tentang persepsi pegawai terhadap penerapan sistem informasi administrasi yang selama ini berjalan pada Puskemas Bayan, maka peneliti dapat menarik kesimpulan sebagai berikut :

1. Sarana dan prasarana Puskesmas Bayan pada tingkat persediaan dan perlengkapannya masih dalam proses pengembangan sehingga menjadi faktor penghambat dalam memberikan proses administrasi yang efektif kepada pasien.

2. Puskesmas Bayan dalam memberikan pelayanan kesehatan kepada pasien umum masih menggunakan sistem manual yang artinya tetap menggunakan perangkat komputer tetapi tidak tersambung jaringan data local area network (LAN) dan tidak menggunakan server sebagai database.

3. Sistem informasi pelayanan kesehatan di Puskesmas Bayan menggunakan mekanisme pelaporan, dimana informasi yang dihasilkan dari data masukan di proses dan akhirnya output yang dihasilkan akan dilaporkan atau dikirim kepada instansi yang bersangkutan.

4. Data keluaran meliputi kegiatan untuk menyajikan dan mendistribusikan informasi yang ada kepada pihak yang membutuhkan, yaitu Departemen Kesehatan Pusat, Dinas Kesehatan Propinsi, Dinas Kesehatan kabupaten/ Kota, Puskesmas Bayan dan Badan Penyelenggara Jaminan Sosial (BPJS). 


\section{Saran}

Berdasarkan hasil penelitian yang telah disimpulkan diatas, maka peneliti dapat memberikan saran-saran sebagai berikut :

1. Sistem informasi pelayanan kesehatan pada Puskesmas Bayan sudah berjalan dengan baik meskipun terdapat beberapa kekurangan di sistem jaringan data local area network (LAN) dan server, jadi sistem informasi hendaknya terus ditingkatkan dengan penambahan sarana prasarana penunjang pelayanan, seperti penambahan locar area network (LAN) dan server sebagai pusat data.

2. Pihak Puskesmas Bayan beserta instansi terkait agar tetap berupaya menyediakan saran dan prasarana penunjang pelayanan kesehatan demi meminimalisasi tingkat kesalahan dan lebih meningkatkan motivasi kerja pada tenaga-tenaga puskesmas di bidang pelayanan medis maupun non medis.

3. Menghadapi era globalisasi dengan semakin canggihnya teknologi informasi sekarang ini, maka sumber daya manusia (SDM) di Puskesmas Bayan harus terus dibekali pemahaman mengenai teknologi informasi (TI) dan penyeleksian pegawai harus dilakukan secara ketat dan profesional dimana sumber daya manusianya harus faham mengenai bidangnya.

Dengan penelitian ini diharapkan Puskesmas Bayan mampu mempertahankan atau mengembangkan pemanfaatan teknologi informasi dalam sistem informasi administrasi pelayanan kesehatan bagi masyarakat Bayan.

\section{DAFTAR PUSTAKA}

[1] Mahmudi. 2005. Menajemen Kinerja Sektor Publik. Jakarta : Gramedia.

[2] Komaruddin. 1974. Manajemen Organisasi Suatu Analisa Sistem. Bandung : Tarsito.

[3] Effendy. 1989. Efektivitas Dan Ukuran Efektivitas. Yogyakarta : Bina Aksara.

[4] Wayne Persons. 2006. Public Policy. Jakarta. Pranada Media Group.

[5] Malik, Oemar. 2007. Dasar-Dasar Pengembangan Kurikulum. Jakarta : Rosda.

[6] Subarsono, AG. 2008. Analisis Kebijakan Publik (Konsep, Teori dan Aplikasi). Yogyakarta : Pustaka Pelajar
[7] Sutabri, Tata. 2003. Analisa Sistem Informasi. Yogyakarta: Andi.

[8] McLeod Jr, Raymond. 2004. Sistem Informasi Manajemen. Jakarta: PT. Prenhallindo.

[9] Wilkonson, Josep W. 2000. Accounting Information System Essential Concept and Application. New York : Jhon Willey \& Sons Inc.

[10] Handayaningrat, Soewarno. 1988. Pengantar Studi Ilmu Administrasi dan Manajemen. Jakarta : CV. Haji Masagung

[11]LAN RI. 1997. Sistem Administrasi Negara Republik Indonesia. Jakarta : PT. Gunung Agung

[12] Muda, Harris Nst. 1962. Kursus Pengetahuan Administrasi Tata Usaha. Medan : Fa Madju Medan.

[13] Moenir. 2000. Manajemen Pelayanan Publik. Jakarta : Bina Aksara.

[14]Ndraha. 2003. Ilmu Pemerintahan Baru. Jakarta : Rineka Cipta.

[15]Ratminto \& Atik Septi Winarsih. 2006. Manajemen Pelayanan. Jakarta : Pustaka Pelajar.

[16] Barata. 2004. Dasar-Dasar Pelayanan Prima. Jakarta : Elex Media Komputindo

[17]Jhon, C Mowen. 1994. Perilaku Konsumen. Jakarta : Binarupa Aksara.

[18] Keputusan MENPAN Nomor 81/KEP/M.PAN/71993 Tentang Pedoman Tata Cara Pelayanan Umum.

[19]Budioro.2001. Pengantar Ilmu Kesehatan Masyarakat. Badan Penerbit : UNDIP

[20]Soekidjo Notoatmodjo.2007. Kesehatan Masyarakat Ilmu Dan Seni. Jakarta : PT. Rineka Cipta.

[21] Arikunto, Suharsimin. 1998. Prosedur Penelitian. Jakarta : Rineka Cipta.

[22] Sugiyono. 2009. Metode Penelitian Kuantitatif dan Kualitatif dan R\&D. Bandung : Alfabeta

[23]Umar, Husein. 2001. Metode Riset Komunikasi Organisasi. Jakarta : Gramedia Pustaka Utama 